Marta Leśniakowska

\section{Experiencing Cultural Visualisations: the Anthropology of (re-)Construction ${ }^{1}$}

DO1:10.18318/td.2015.en.2.17

1

It is a question of substituting the signs of the real for the real, that is to say of an operation of deterring every real process via its operational double $[. .$.$] simulation threatens the difference$ between the "true" and the "false," the "real" and the "imaginary."

Jean Baudrillard, The Precession of Simulacra ${ }^{2}$

These are the forms the city could have taken if, for one reason or another, it had not become what we see today.

Italo Calvino, Invisible Cities ${ }^{3}$

Matters of art often start where matters of life end. Life begins with birth; artwork may

1 The presented text is an extended version of the paper presented at the 36 th Conference on Literary Theory Cultural Visualisations of Experience, organised by the Department of Historical Poetics and Art of Interpretation of the Silesian University and the Department of Historical Poetics in the Institute of Literary Research of the Polish Academy of Sciences, Złoty Potok, September 18-21, 2008. Jean Baudrillard, The Precession of Simulacra, trans. Sheila Farla Glaser, accessed September 15, 2015, http://www.egs.edu/faculty/ jean-baudrillard/articles/simulacra-and-simulations-i-the-precession-of-simulacra/.

Italo Calvino, Invisible Cities, trans. William Weaver (San Diego, New York, London: Harcourt Brace \& Company, 1974), 32.
Marta Leśniakowska

- associate professor, historian of art, professor of the Institute of Art of the PAN, visiting professor at many universities. Her broad research interests include the study of the modern artistic culture and its theory, the methodology of history of art, the theory of visual culture in the transdisciplinary perspective. Author of numerous articles published in scholarly publications and of ten books which include inter alia Polskidwór: wzorce architektoniczne, mit, symbol (1992), Co to jest architektura? (1996); Architekt lan Koszczyc Witkiewicz (1881-1958) i budowanie wjego czasach (1998), and the series Architektura wWarszawie. She was cecorated by the Minister of Culture and National Heritage with the Medal for Merit to Culture Gloria Artis (2014). 
be born among the destruction: under the rule of ashes, in escape into mourning, due to absence.

Georges Didi-Huberman, Génie dunon-lieu ${ }^{4}$

The proposed analysis of modernity from the perspective of critical postmodernist art history is aimed at showing how this perspective changes the relationship with images. What happens when the problem of image as a cultural visualisation of experience, that is as speakable language, is turned into a question of experiencing the image itself? The field of observation will be the analysis of experiencing a certain (specific) image of a city as a "record of social participation" (as Bourdieu would say) in which memory is observed, becoming visible as a performative category. The category of media spectacle as presentation - not representation - will emerge, while the titular anthropology of (re-) construction is concerned with the analysis of an aesthetic experience which leads to the generation of memory as a cultural experience and to the rehabilitation of the notion of emotion in perceiving/experiencing art. Consequently, following Gernot Böhme's aesthetic theory of emotional states [Befindlichkeit] or mood, the sentimental involvement will be put into focus. This will allow for the depiction of sensual/corporeal presence a ga inst and with in image, which eventually will reveal the role of image as part of an aestheticized reality - the reality in which the creator consciously generates mood, implementing the politics of mood together with its hidden impact. ${ }^{5}$

In his book Imagining the Modern City (1999), a radical critic of culture James Donald treats the city as an "imagined environment." Not losing sight of the fact that "of course real cities exist," he asks:

But why reduce the reality of cities to their thinginess, or their thinginess to a question of bricks and mortar? States of mind have material consequences. They make things happen. Starting from there, what particularly interests me is the power of the city as a category of thought. The city is an abstraction, which claims to identify what, if anything,

4 Georges Didi-Huberman, Génie du non-lieu. Air, poussiere, empreinte (Paris: Hantise, 2001), 9 [translation M. Skotnicka]

5 Cf. Gernot Böhme, Filozofia i estetyka przyrody w dobie kryzysu środowiska naturalnego, trans Jarosław Merecki (Warszawa: Oficyna Wydawnicza, 2002); "Współczesna rehabilitacja estetyki przyrody. Na marginesie projektu Gernota Böhmego. Dyskusja redakcyjna," Sztuka i Filozofia (2004): 5-54; Stanisław Czerniak, "Pomiędzy Szkołą Frankfurcką a postmodernizmem Antropologia filozoficzna Gernota Böhmego na tle klasycznych stanowisk antropologii filozoficznej XX wieku, "foreword to: Gernot Böhme, Antropologia filozoficzna. Ujęcie pragmatyczne [wykłady z Darmstadt], trans. Piotr Domański, foreword and editing of the translation Stanisław Czerniak (Warszawa: Wydawnictwo IFiS PAN, 1998), VII-XLVII. 
is common to all cities. [...] The city we do experience - the city as state of mind - is always already symbolised and metaphorised. ${ }^{6}$

The artist Aleksandra Polisiewicz's project entitled Wartopia (2005) is precisely about the "imagined city," a simulacrum, a city as a state of mind. At first glance, it is read as a typical computer rendering of virtual urban planning. Reception of the work radically changes once the viewers learn about the genesis of the project which places them in a disturbingly ambiguous situation [illustration 1-11].
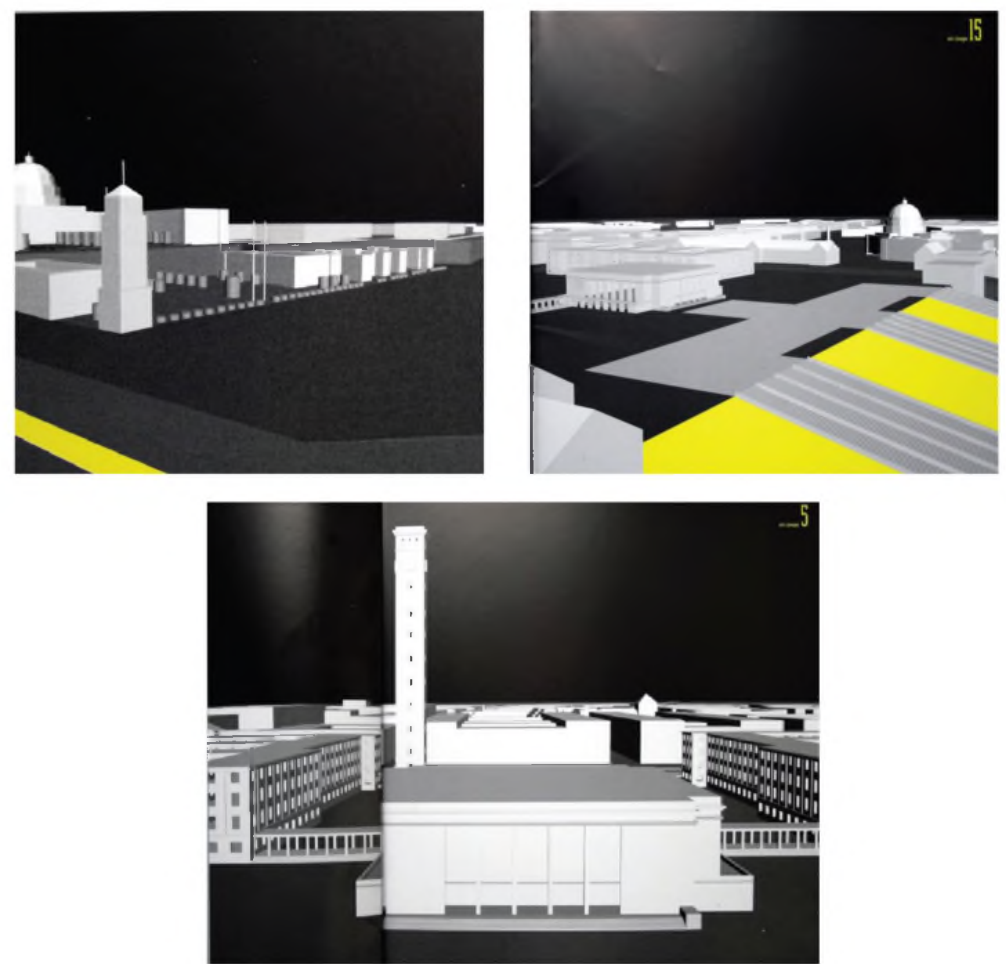

6 James Donald, Imagining the Modern City (Minneapolis: University of Minnesota Press, 1999), 8,17 , quoted after Janet Wolff, "Kobiety i nowoczesne miasto. Refleksje na temat flaneuse," in Co to jest architektura? Antologia tekstów, ed. Adam Budak (Kraków: Manggha. Muzeum Sztuki i Techniki Japońskiej, 2002), 260. 

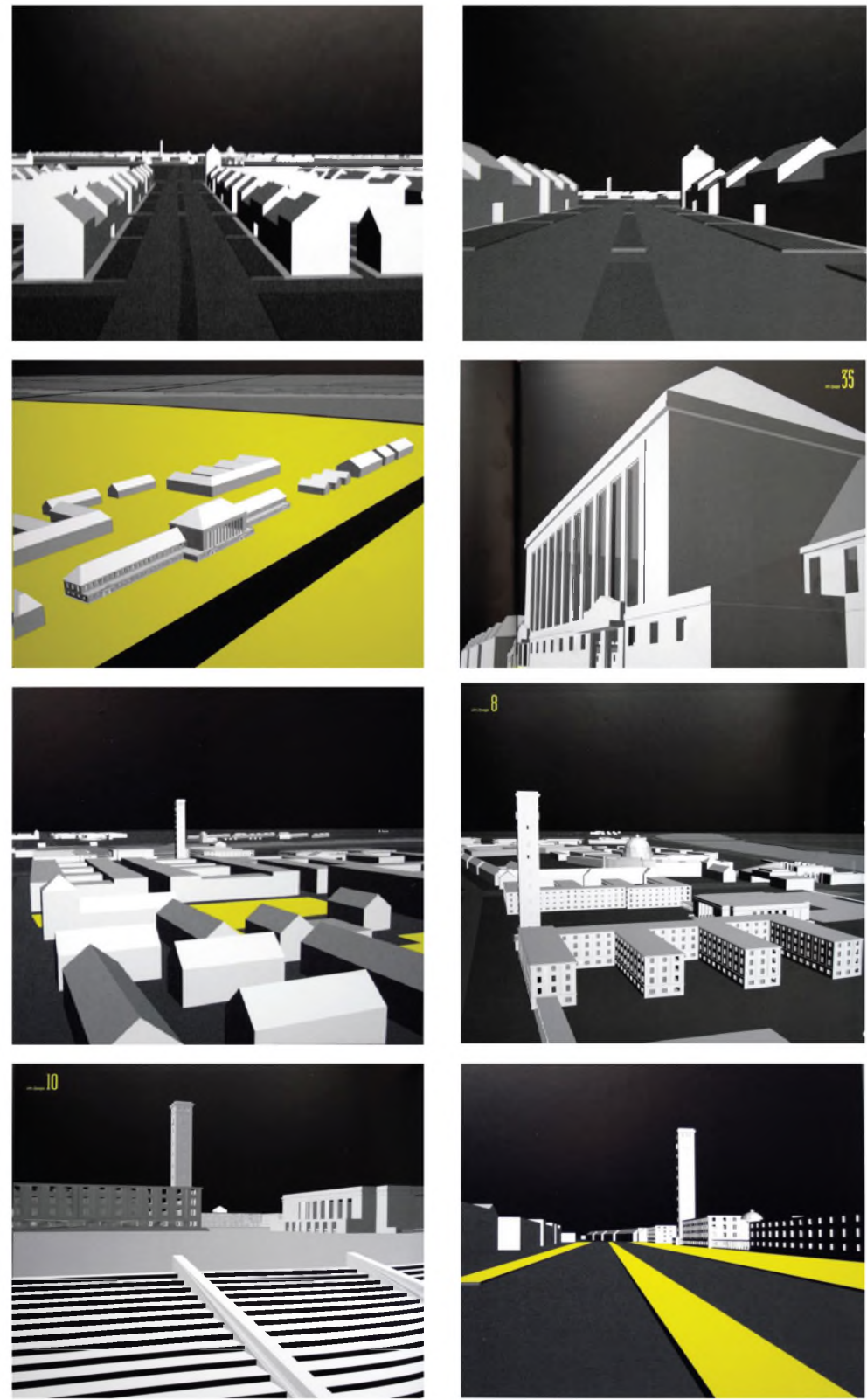

1-11. Aleksandra Polisiewicz, Wartopia, 2005 
The starting point of Wartopia are urban concepts of Nazi city planners developed during World War II which necessitated the complete destruction of Warsaw and replacing it with a newly built German city (Die Neue Deutsche Stadt Warschau) reduced to around 40 ooo inhabitants and dedicated to Germans only [illustration 12].

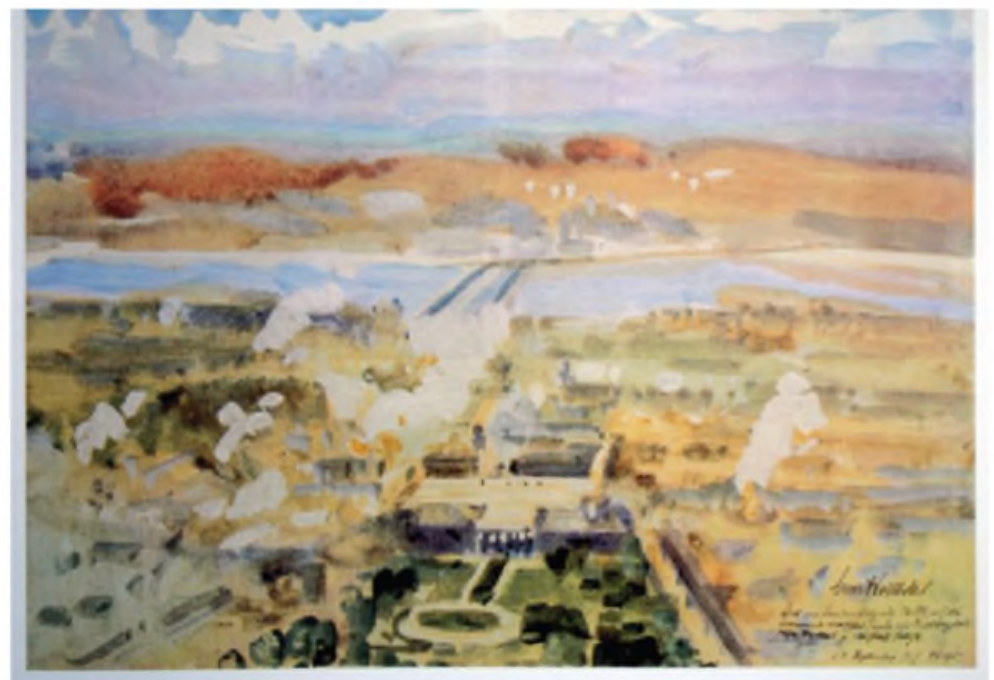

12. Cityscape of Warsaw, watercol ar by Ernst vallbehr, from the exhibition "Expedition to Poland in Fictures and Photographs," Berlin 1940.

The radical character of these plans - by no means dystopian, as they genetically originated equally from urban planning fantasies of 18 th and 19th century visionaries and the utopias of 2oth century's first avant-gardes [illustration 13-15]

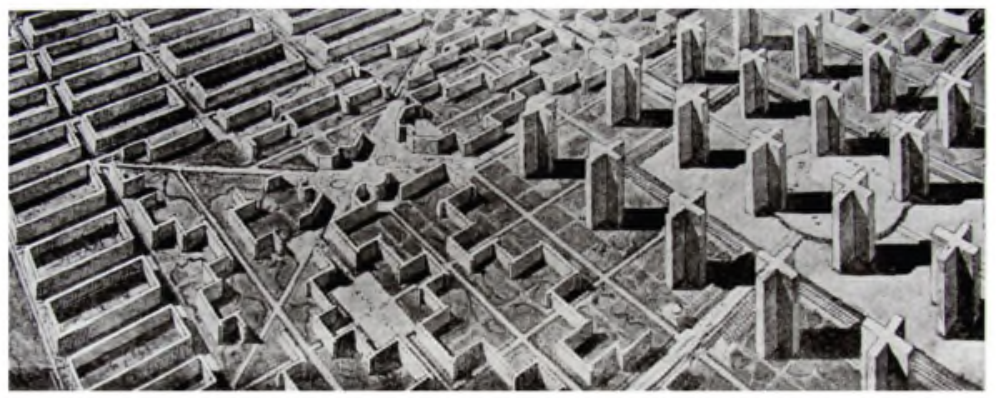

13. Le Corbusier, Diorama of the Contemporary City for Three Million Inhabitants, Paris Salon d'Automne of 1922. 

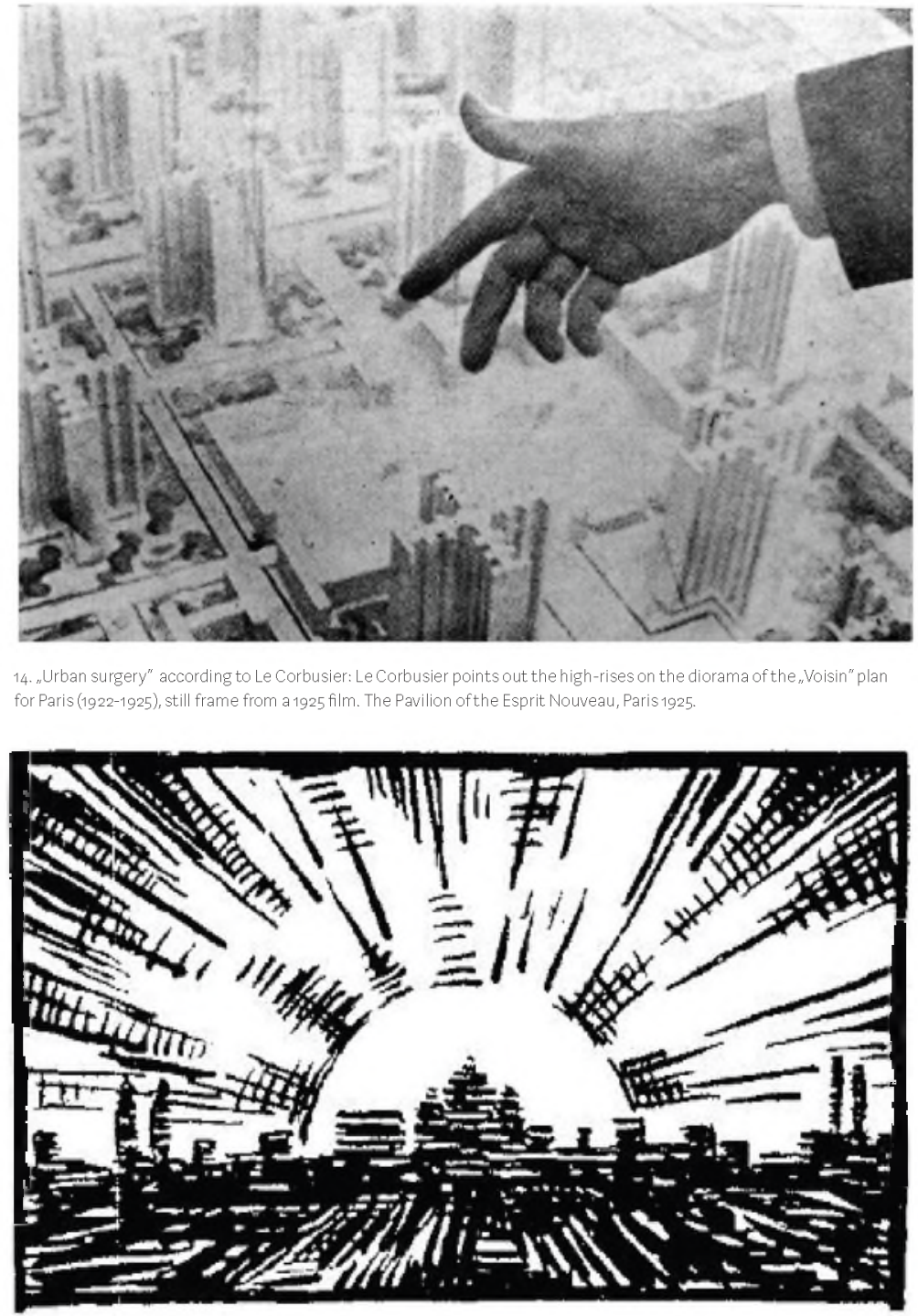

15. Bruno Taut, Die Stadtkrone, a project of an ideal city, 1917.

filtered through Germanic myths of cultural colonisation - assumed creating an entirely new space meant to take the place of the city erased from the map. Such an initiative - supported by the dream of tabula rasa and Le Corbusier's 
concept of "urban surgery"7 - enabled the realisation of the old founding myth of the New Beginning, "from the founding of the city" identified with the New History written for the New Man who "changes his environment and himself with it"8 [illustration 16].

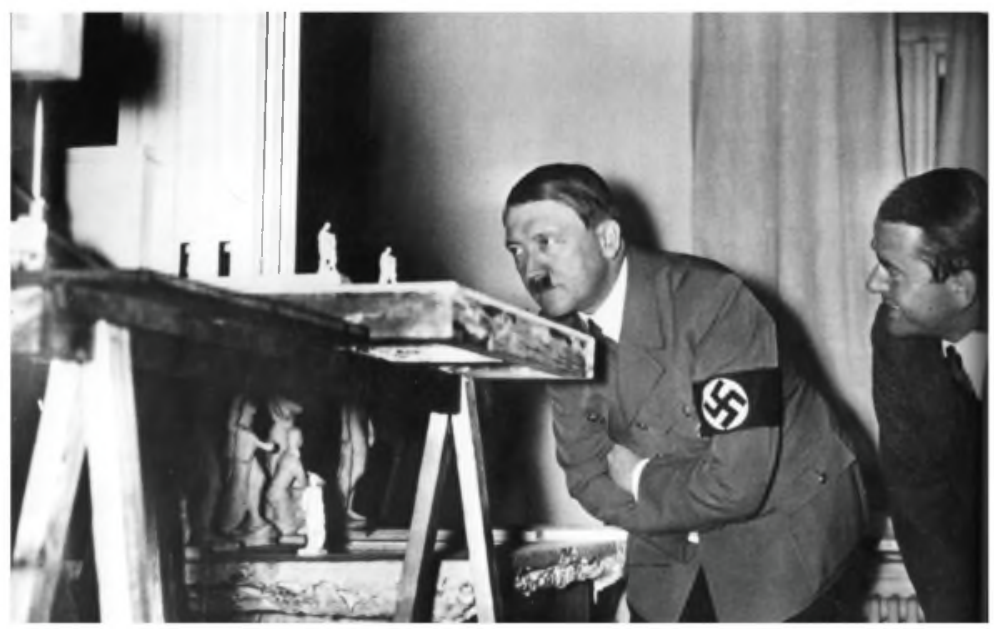

16. Ado If Hitler and architect Al bert Speer standing next to the model of the German pavilion for the 1939 World's Fairin New York.

Out of the three time dimensions - past, present and future - the first was already deemed obsolete. Since the 1920s, influential German architects and art historians of the Weimar Republic such as Hans Hildebrandt and Cornelius Gurlitt, and institutions such as Freie Deutsche Akademie des Staedtebaus (Free German Academy of Urban Design) and the Construction Committee in Hamburg, scrutinised Le Corbusier's modernist ideas based on the concept of tabula rasa, regarding them as confirmation of the thesis that "the city of today, and certainly the city of tomorrow, has little in common with the city of the past." 9 Theories of new urbanism, embedded in the

7 According to Le Corbusier, the vision of New Paris, "Plan Voisin" from 1923-1925, based on the "surgical" removal of the old town, "liberates" the city and introduces geometry to the nature or to the chaos of traditional urban agglomerations (Le Corbusier, Urbanisme, 1925).

8 Le Corbusier, Urbanisme, 1925, quoted after: Niels Gutschow, Barbara Klein, Zagłada i Utopia. Urbanistyka Warszawy w latach 1939-1945 (Warszawa: Muzeum Historyczne m.st. Warszawy, 1995), 15

9 Hans Hildebrandt in the introduction to the Germanedition of Le Corbusier's Urbanisme Staedtebau (Berlin-Leipzig, 1929) after Niels Gutschow, Barbara Klein, Zagłada i utopia, 15. 
national-socialist (and analogically - communist) programme became the foundation of the new order in the 2 oth century.

The Nazi plans for Warsaw prepared in the years 1939-1943 by Hubert Gross, Oskar Dengel, Hans Hubert Leufgen, Friedrich Gollert (author of the book Warsaw Under the German Rule, 1942) and Friedrich Pabst within the framework of Hitler's "Germanisation of the East" and cultural colonisation, are well known to art historians [illustration 17].

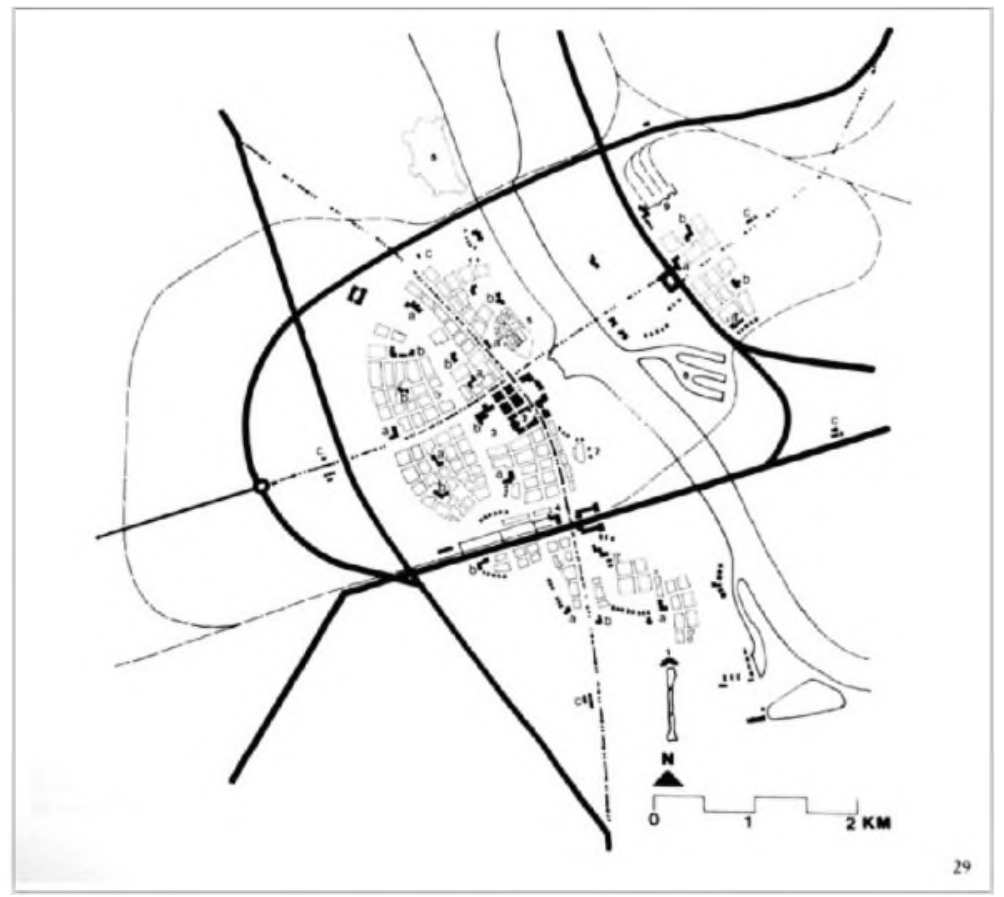

17. Die Neue Deutsche Stadt Warschau, city plan,1939/40

Mistakenly called the "Pabst Plan," they were carefully analysed in the 1990 s by two Polish and German scholars who, in their interpretations, deliberately adopted the perspective of "perpetrators" instead of victims. However, the cultural situation after the Holocaust brought to light by Adorno could not be omitted or ignored in these analyses. Niels Gutschow, an architect representing the post-war generation and the son of an architect who supported the national-socialist programme during the war, asks, "Is urbanism possible after the experience of Auschwitz?" And he answers: 
Most probably this question has never been posed because architects and urban planners, both in Germany and Poland, were not afraid of tabula rasa. On the contrary, as representatives of a professional group feeling the vocation to design cities of the future in any circumstances, they were expecting it. The simultaneity of destruction and utopia will appear incomprehensible and astonishing only to the next generation. ${ }^{10}$

Aleksandra Polisiewicz, young Polish artist, uses the archives to read the Nazi urban plans of Warsaw anew. Hiding her female identity, she takes on an attitude of ostensible objectivism and distance typical of the contemporary post-colonial situation. It enables her to obtain her goal: to perform a Freudian disclosure, i.e. bring out what was and/or was supposed to be concealed in order to re/write the history. The artistic tactics of Aleksandra Polisiewicz oscillates between modern art strategies which relate to the problem of (re) construction of history and, by referring to psychoanalytical practices aimed at liberating the images of representation, problematises the issues of mediating memory. Such a visualization situates Wartopia in the area of critical art of post-memory.11

At first glance, Aleksandra Polisiewicz "only" makes computer reconstructions of history which update the Nazi visions with the use of $3 \mathrm{D}$ techniques and movement. She creates images specific to the aesthetics of computer graphics: flat and colourless, with a narrow palette and "bare," stereometric, roughly moulded solids exposed by sharp, contrasting lighting coming from an "extraterrestrial" source, impossible to locate. These synthetic images straightforwardly demonstrate the intention of overwhelming the viewer: their visual attractiveness makes the Nazi architecture turn into a "fascinating fascism" - as Susan Sontag described Nazi aesthetics ${ }^{12}$ - which introduces the viewer to the "re-enchantment of the world" and "reactivation of mythical powers," acknowledged by Benjamin and Adorno. ${ }^{13}$ For we do not observe here a computer image treated as an allegedly objective, transparent medium helping deliver a reconstruction/model identical with its primary source. Animations and complementary static images-frames shown on the screen seem to be staged,

10 Hildebrandt, 10-11.

11 Cf. Bartosz Korzeniecki, "Medializacja i mediatyzacja pamięci - nośniki pamięci i ich rola w kształtowaniu pamięci przeszłości," Kultura współczesna 4 (2007), 5-23.

12 SusanSontag, "Fascynujący faszyzm," Magazyn Sztuki 12 (1996), 123-136.

13 Walter Benjamin, Anjołhistorii. Eseje, szkice, fragmenty, ed. Hubert Orłowski (Poznań: Wydawnictwo Poznańskie, 1996); Theodor Adorno and Max Horkheimer, Dialektyka Oświecenia. Fragmenty filozoficzne, trans. Małgorzata Łukasiewicz (Warszawa: Czytelnik, 1994). 
resembling a performed landscape, an architectonic spectacle of "pure form" of the solids' geometry, suspended in an abstract, endless landscape. Aleksandra Polisiewicz's cybercity shapes an ambivalent image of the fictional world - like in a computer game - founded on a monumental, modernised classicism, stereotypical of fascist architecture associated with Hitler's architect Albert Speer. The cultural cliché of so-called Nazi architecture, therefore, dug out from the "memory system" as "a ready image" that undergoes appropriate processing, equally concerns the problem of falsity/utopia of modernist "truth" as cultural hypostasis and fantasy (the problem of the falsity of "reconstruction") as well as the emotions and obsessions which are present in the collective imagination determining social life. Taking up the problem of mythologisation of totalitarian systems and memory ruins, Polisiewicz deliberately employs the image of "bare" architecture: deprived of decorum, extremely synthetic solids are the figures of architectural bare bodies in their essentialism, bonding architecture and body within a single system of power. ${ }^{14}$

Wartopia's $3 \mathrm{D}$ urban visions deploy animation. Thus they have all the features of a fictional film projection. It is the gist of what the theory of film - occupied with perception of image - defines as the "dynamic screen" (Lev Manovich): the relation between the moving image and the motionless body of the viewer who experiences the moving world in the image through the eye connected with the camera transmitting him into virtual space. In this relation "between the body and image," states Hans Belting, the representation of image remains linked with the screen, whereas the synthetic image with users and their graphic desires inspired by haptic sensual experiences, mystical metaphor and hyperreal space. This is why the perceiving Polisiewicz's cyberimages seems to require evoking the synthetic image's novel features discovered by Belting when he points to the viewers and their receptive behaviour. Especially in view of what Bernard Stiegler calls "the discreet image," since "the image does not exist at all" and is only the "remnant," the "trace and inscription" of images mediated by the current media. This perspective allows us to interpret the current experience of the image anthropologically. Belting also reminds us that the deconstruction of the mimetic truth of images which takes place in digital imaging, did not begin concurrently with the emergence of digital technology - this topic has been the focus of all avantgardes of the 2oth century which undermined the traditional "trust towards image" and replaced it with "the fascination with the media spectacle," which exposes its effects and generates its own graphic reality. ${ }^{15}$ According to the

Cf. Jo Anna Isaak, "Representation and its (Dis)contents, "Art History 3 (1989): 362-366. 
anthropological perspective, says Belting, technical images are thus analysed from the point of view of their function in the media dialogue with the viewer. Simulation and animation play key roles here - they are the two achievements of fantasy, pushing the borders of the imagination which had already been present in Renaissance paintings, considered to be constructs of the precisely measured visual field. By showing "what happens between images today," the motion image of new media (e.g. computer animation) cannot avoid being studied against the psychology of perception and Deleuze's film theory introducing the sensorimotor situation, including dream-images and memories. ${ }^{16}$ Wartopia may be situated in this perspective as well: as a dreamimage in Deleuze's understanding.

The artist used two kinds of images - animation and motionless renderings - to compose a hybrid out of two different media: film and photography. Independently of the medium, however, it is always about the image. In Wartopia, it is the "found" image: retrieved from the archive is the unrealised vision of Warsaw, designed by the Nazi architects and ideologists at the beginning of World War II in order to transform the historical capital of Poland into a garrison town for the "herrenmensch" of New Germany. We could thus quote after Belting that Wartopia is both the image of memory and the image of representation. ${ }^{\mathbf{1 7}}$ In computer animation, we experience the cyberspace linked with the image of the city that is hypothetical, but still possible to realise.

What is more important here, however, is the dystopian quality of Wartopia understood as an instrument of interpreting the world. We might assume (after Andrzej Turowski via Foucault) that Hubert Gross and Friedrich Pabst's urban plans are pseudoheterotopias. In his interpretation of Wartopia, Turowski recalled the discrepancy between utopia and dystopia; the former emerges on the ruins of reality, the latter on the ruins of utopia. Utopias and dystopias are places deprived of real space but this only seemingly allows for considering the Nazi designs - and particularly Wartopia - as belonging to any of the two categories. It appears closer to pseudotopia and pseudoheterotopia - urban hybrids having no specific location because such geographic indication would in fact only simulate the knowledge of "where Warsaw once was."

Heterotopias parasitising utopias try to locate them in space by which the space is embedded in the mythical or political order linking it with time and people. [It is a kind of] effectively performed utopia in which

16 Ibid. 52-59.

17 Ibid., 103, 113 . 
all other real places that can be found within culture are simultaneously represented, contested and reversed.18

Foucault's perspective - defining heterotopias as places which are antithetic or alternative to the ones we live in - helps diagnose the current process of ousting heterotopias by the virtual reality of images, "virtual space outside of the world space," as Belting puts it, i.e. as an image of a certain place, for instance a city, which is reflected in its counter-image. And "everywhere we use our eyes to search for places our bodies cannot access, we come across the tangle of references between places and images of places which is almost impossible to be resolved."19 The same situation can be encountered in Wartopia. As a VR (virtual reality) project, it introduces the viewer to a different reality whose aesthetically modelled artificiality ${ }^{\mathbf{2 0}}$ is felt so intensely that we are able to immerse in it deeper that in the film image - one of the reasons being the lack of distance characteristic to film and television. In VR, the distance is abolished which enables the viewer to experience the state of immersion in the image to such a degree that VR attains the status of a natural environment, functioning similar to eroticism. ${ }^{21}$ The latter evokes an "ontological shift": this world does not exist but its effects do. ${ }^{22}$ This is because virtual reality, continuing the tradition of simulation, introduces one

18 Andrzej Turowski, "Ekran miasta," in Aleksandra Polisiewicz Wartopia, Berlin - 518, Moskwa1122, Exhibition Catalogue (Warszawa: Galeria Le Guerr, 2006-2007), 63-63; Michel Foucault, Inne przestrzenie, trans. Agnieszka Rejniak-Majewska, Teksty Drugie 6 (2005), 120.

Hans Belting, Antropologia obrazu..., 82-83.

20 Wolfgang Welsch, "Procesy estetyzacji - zjawiska, rozróżnienia, perspektywy," in id. Estetyka poza estetykq, trans. Katarzyna Guczalska, ed. Krystyna Wilkoszewska (Kraków: Universitas, 2005), 51 .

21 See Joanna Walewska, "Wirtualność jako przyszłość mediów. Spojrzenie estetyczno-filozoficzne," Pośrodku. Pismo Instytutu Sztuk Audiowizualnych U/ (2006): 18-23. "Suspended in computer space, the cybernaut leaves the prison of the body and emerges in a world of digital sensation, "Michael Heim, The Erotic Ontology of Cyberspace (New York: Oxford University Press, 1993), accessed September 10, 2015, http://yin.arts.uci.edu/ studio/readings/heim.txt http://yin.arts.uci.edu/ studio/readings/heim.txthttp://yin.arts.uci.edu/ studio/readings/ heim.txt Heim mentions seven features of VR: simulation, interaction, artificiality, immersion, telepresence, full-body immersion, networked communication. Tadeusz Miczka, O zmianie zachowań komunikacyjnych. Konsumenci w nowych sytuacjach audiowizualnych (Katowice: Księgarnia św. Jacka, 2002), 107. "Reality cannot be both real and unreal and since it is unreal and its agentive effects are real, it's hard to clearly determine its ontological status," Monika Miczka-Pajestka, Podmiot j jego cyfrowa egzystencja in Estetyka wirtualności, ed. Michał Ostrowicki (Kraków: Universitas, 2005), 421. 
fundamental difference: it is no longer a fake space developed from a "normal" space, but it is space in which physical reality is disregarded, dismissed or abandoned. ${ }^{23}$

According to Belting, between images and places, there are connections which have not yet found their commentators: "Just as we may speak about the body as the place of images, we may also speak about geographical sites which only gained popularity due to artworks located in these places."24 It is a good starting point to observe how Wartopia sublimates the notion of place, being only an image of place which solely exists in the form of an image. This situation is accounted for by the anthropology of image, which indicates that visiting a place existing only as an image causes a shift in an image-place relation: the image becomes "the place of the unplaced" with no correspondence to real places and exists only as a metaphor. The graphic presence of absent places is of course an old anthropological experiment where the relationship between imaginary places and the real ones alters. ${ }^{25}$ In Belting's view, this process can be explained with the help of "ethnology of one's own environment" (M. Augé) which finds its equivalent "in the gaze of those who suddenly re-discover the images of their own culture in museums and archives, and where history of images requires explanation, similarly to the images of other cultures - open to hermeneutic interpretation." 26 The problem which is analysed here concerns the relationship between image-memories and the collective memory of culture whose technical body remains in the institutionalised memory of archives, which gets activated (animated) through collective imagination by both forgetting and recalling, granting the past a visible place in the present.

This context also embraces the issue of "reconstruction" bearing resemblance to the museum as a reservoir of memory-images. There are no doubts about Foucault's thesis that, due to their relation with time caesuras, museums are "alternative places or heterotopias produced by modernity:"27 the

23 Lev Manovich, An Archeology of a Computer Screen, accessed September 18, 2015, http:// manovich.net/content/o4-projects/o11-archeology-of-a-computer-screen/o9_article_1995. $\mathrm{pdf}_{t}$ 27-28: "Previously, the simulation depicted a fake space which was continuous with and extended from the normal space. [...] In VR, either there is no connection between the two spaces (for instance, I am in a physical room while the virtual space is one of an underwater landscape) or, on the contrary, the two completely coincide [...]. In either case, the actual physical reality is disregarded, dismissed, abandoned."

24 Belting, Antropologia obrazu, 76.

25 Ibid. $77,80-81$

26 Ibid. $83-84$ and further.

27 Foucault, quote after: Belting, Antropologia obrazu, 86. 
heterotopicality of the museum makes it belong to another time than its own collection, while its role lays in creating a place beyond the time when these items took part in the life process. Belting specifies that the museum, excluded from the flow of time, is dedicated to images representing another time which makes them symbols of memory, carrying certain understandings of the past:

In the museum, we replace the world we live in with the place we understand as the image of place of yet another kind. We perceive artworks we see in the museum as images painted for another time which nevertheless belong now to the museum only. It seems that world cultures are moving away from books and museums where they are archived, but not animated any more. ${ }^{28}$

In this pessimist view of the imaginary place, place exists only as an image inscribed in the modern (individual or collective) experience. Wartopia as a "reconstruction" of memory/place straightforwardly appeals to this concept. An imaginary place is what Benjamin describes as "seizing hold of a memory:"29 it resembles images produced in a dream, inaccessible in reality but perceived solely as image. This gives Wartopia the quality of a movie screen.

The scenario of Wartopia is constructed by means of comparing two complementary types of images: computer animation and motionless images repeating shots from animation. This simple idea refers to two types of time and perception: active and passive. The state close to hallucination and dream (described by film theoreticians Marc Augé and Christian Metz), which the viewer falls into during the film, is particularly apparent in such computer animations which draw the viewer inside the image. Consequently, the moving visualisation of architecture, which only creates a suggestion of the real experience, is closer to the state we are in while dreaming. The radical application of time upon an image, mentioned by Belting, ${ }^{30}$ is typical of films where the viewer identifies himself with the imaginary situation, while mental images entertained by the viewer can be identified with images of technical fiction. This is almost perfectly exemplified by Wartopia which reveals its ambiguity by mixing the real with the fictional. The plans - existing in reality, although

28 Ibid., 86 .

29 "To articulate the past historically does not mean to recognize it'the way it really was' (Ranke) It means to seize hold of a memory as it flashes up at a moment of danger, "Walter Benjamin, Theses on the Philosophy of History (New York: Schocken Books, 1969), 255. 
never put to life - lead to technofiction, a cyberutopia which, as Belting claims, "promises, with technological pathos, liberation from references to the real world." 31

Wartopia, therefore, is pure Virtual Reality (VR) endowed with the new, technological authority of fiction which appears to be real. Aleksandra Polisiewicz's project may be perceived as a direct reference to the situation diagnosed by Belting who had observed how modern art was becoming increasingly technological and used technology to create mental images and images of memories which are then offered to our graphic memory as quotations.

The artist's project enters into a polemic with zoth century art as we know it from institutional discourses and spaces. "Reconstruction" (I'm using the quotes here on purpose) tells an unrealised story; its assessment performed by official Polish historiography is unequivocally negative in view of the idea of tabula rasa put to life within Germany's colonisation policy. Computer images of Wartopia, however, also reveal what stands behind and beyond this politically functionalized assessment: they turn into a critical art history aimed at something more than only exposing the ambiguity of the official interpretation. The Nazi plans retrieved from the archives considered to be the reservoir of history, are typical objet trouvé which tell a new history. Subject to purely aesthetic processing, the cyber-vedutes use their painting-like quality to show what has been deliberately omitted and/or ruled out from earlier interpretations of the Nazi plans: not only, or not exclusively, the menace of the totalitarian city but also the dangerously tempting beauty of "fascinating fascism" symbolised by the monumental and modernised neoclassicism. Buildings suspended in black, cosmic emptiness of the endless landscape, clinically pure and deprived of people, tempt, hypnotise and fascinate. The cybercity loses its identity and its bond with reality as a geographical site and becomes an abstract space of pure fiction but also a "new mirror" reflecting architecture as an image-metaphor of the world. The question about "the truth of reconstruction" is not legitimate any more, since the analysed German projects have been complemented by the artist with components that the originals had been missing, such as elements borrowed from the model residential district (Wilcze Gardło) built in Gliwice (the artist's hometown) for SA and SS members who inhabited it between 1937 and 1941.

In the virtual model of Wartopia as a "simulated city," the stereotypical image of so called fascist architecture is designed to evoke the recipient's psychoemotional reactions. What gets displayed is the mechanism of falsifying history artistically represented by "reconstructions." Not incidentally, the latter 
keep all the qualities of a "beautiful vedute" - ideal topographical images. The new medium unveils its hidden trait, but by no means does it eliminate the old conflict of pictorialism and documentalism. It only dismisses the documentalist claims in favour of the computer-made spectacle (presentation) where the main role is played by the old category of beauty, getting in through the back door.

Aleksandra Polisiewicz's project is a narration which reveals all the rules of the psychological influence of architecture. According to the artist's intentions, the second part of Wartopia is supposed to be the sarcastic "continuation" of her critical history of totalitarian systems in this part of Europe. Although the Nazi plans remained on paper, the idea of tabula rasa which had governed them was implemented within the second totalitarian regime. The latter part of Wartopia is meant to describe the "reconstruction" of socialist Warsaw prepared by architect Edmund Goldzamt, a graduate of the Moscow Architectural Institute and the main ideologist of Polish social realism. Almost at the same time when Hubert Gross was drawing the "Abbau der Polenstadt" ("Liquidation of the Polish City") plans with the national-socialist Gauforum tower in its centre and Friedrich Pabst was sketching the Volkshalle in place of the Royal Castle, Goldzamt was designing the new Socialist Warsaw, with

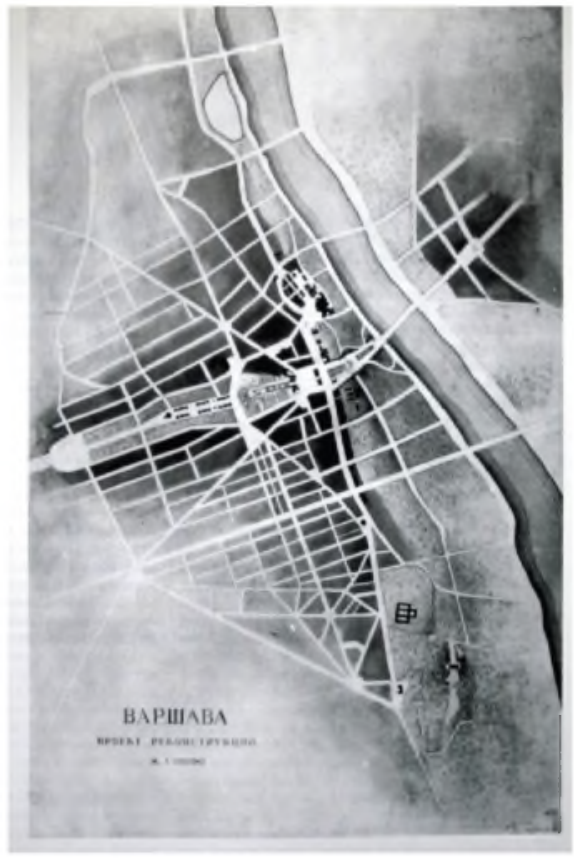
the Liberation tower-monument next to the Pantheon of Revolutionaries [illustration 18-19] in the spirit of tabula rasa. Simultaneously, leftist architects associated with Helena and Szymon Syrkus and their Architecture and Urban Design Studio in Żoliborz (Warsaw) consistently developed the vision of functionalistic "Warszawski Zespół Miejski" (1940-1945) by introducing - after Le Corbusier (just like the Nazis) - the "geometry into the chaos" of the historical structure of the city. Some of these ideas 


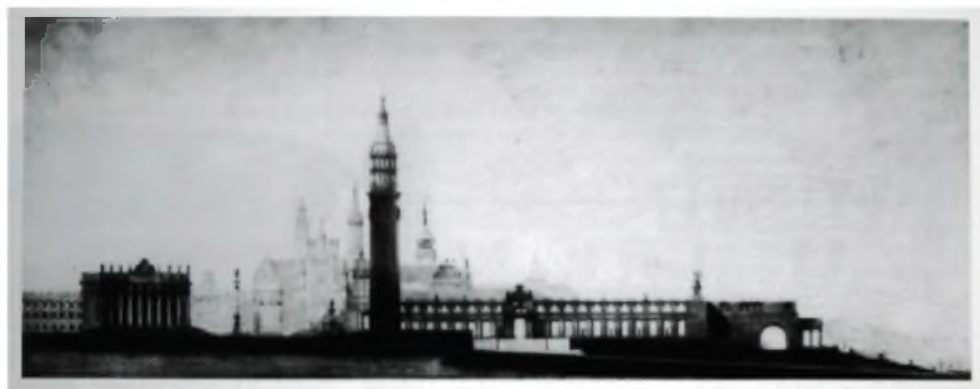

19. Cityscape of Socialist Warsaw, project, illustration by Edmund Goldzamt, Moscow 1945.

were implemented during the post-war "restoration" as figures of the new order.

The two totalitarian visions: fascist and communist which affected one European city within a short period of time are more than signatures of the dystopian dimension of the 2 oth century. By means of the digital medium used by Aleksandra Polisiewicz, they turn into the critical discourse concerning the crisis of presentation and representation, trapped between the problem of the modernist truth, postmodernist representation and postmodernist experience as a spectacle. ${ }^{32}$

Translation: Marta Skotnicka

32 Cf. Frank Ankersmit, Narracja, reprezentacja, doświadczenie. Studia z teorii historiografi, ed. Ewa Domańska (Kraków: Universitas, 2004). 